\title{
HUBUNGAN ANTARA PERSEPSI SISWA TERHADAP TUNTUTAN DAN HARAPAN SEKOLAH DENGAN DERAJAT STRES SISWA SEKOLAH PLUS
}

\author{
Uy Gusniarti \\ Universitas Istam Indonesia
}

\begin{abstract}
Abstrak
Penelitian ini bertujuan untuk mencari hubungan antara persepsi siswa terhadap tuntutan dan harapan sekolah dengan derajat stres siswa of SMU plus. Pengambilan data dilakukan di Sekolah Menengah Umum Negeri 8 Bukit Duri Jakarta Selatan. Subyek penelitian adalah siswa kelas satu dengan usia 14-17tahun sebanyak 81 orang. Teknik sampling yang digunakan adalah simple random sampling. Data dipenoleh dari skala untuk mengukur persepsi siswa terhadap luntutan dan harapan sekolah dan skala untuk mengukur stres siswa. Hipotesis penelitian diuji dengan ui statistik Rank Spearman. Hasil korelasidiperoleh is $=0,4774$ (taraf signifikansi $95 \%$ dengan thitung $=4,8291$. Hal ini menunjukkan bahwa terdapat hubungan positif antara persepsi siswa terhadap tuntutan dan harapan sekolah dengan derajat stres siswa. Atinya semakin siswa mempersepsikan tuntutan dan harapan sekolahnya sebagai ancaman dan bebar, semakin tinggi stres yang cenderung dirasakannya Tuntutan dan harapan sekolah terbesar yang siswa rasakan adalah yang berhubungan dengan keharusannya mencapai prestasi dan keunggulan $(r s=0,4499$ dengan thitung $=4,477.5$ ) serta adanya pengayaan kegiatan belajar mengajar ( $r s=0,2266$ dengan t hitung $=2,0679$ ). Tuntutan dian harapan sekolah dalam hal kedisiplinan tidak dirasakan siswa sebagai beban $(r s=0,1153 d e n g a n t h i t u n g=1,0317)$. Tingkatstresyangtinggi pada $50,62 \%$ siswa tidak membuat siswa menurun prestasinya, tetapi dapal membual siswa merasa tertantang untuk beprestasi lebih baik.
\end{abstract}

Kata-kata Kunci: Persepsiterhadaptuntutan dan harapan, derajatstres,
sekolah plus

\section{PENDAHULUAN}

B angsa Indonesia saat hi sangat membutuhkan sumber daya manusia yang siap pakai dan sesuai dengan dunia kerja yang ada. Tantangan global dalam persaingan antarbangsa yang semakin nyata serta agenda pembangunan menuntut sumber daya manusia yang memiliki kualitas tinggi (unggul) yang tidak hanya mampu bersaing dalam lingkungan nasional melainkan juga dalam dunia intemasional. Oleh karena itu, peningkatan dan pemerataan mutu pendidkan pertu mendapat perhatian yang besar. Pemerintah, dalam hal ini Departemen
Pendidikan dan Kebudayaan, menjadikan peningkatan dan pemerataan mutu pendidikan sebagai prioritas. Salah satu strategi untuk meningkatkan dan memeratakan mutu pendidikan adalah dengan mendorong peran serta masyarakat dan swasta. Peran serta tersebut diantaranya ialah dengan mengembangkan sekolah-sekolah plus yang dikenal juga dengan sekolah unggulan (Achmady, 1995).

Sekolah Menengah Umum Negeri 8 Jakarta adalah SMU plus yang merupakan SMU Negeri tanpa asrama yang dipersiap- 
kan oleh Kantor Wilayah Departemen Pendidikan Nasional untuk dapat dikembangkan menjadi SMU yang memiliki ciri-ciri plus. Salah satu cirinya yaitu dengan melaksanakan kurikulum yang diperkaya (Dikdasmen, 1996). Di samping menyelenggarakan pendidikan setiap hari seperti halnya sekolah menengah umum yang lain dari pukul 06.45 sampai dengan pukul 12.30, sekolah ini juga memberikan tambahan jam pelajaran atau bimbingan belajaryang diasuh oleh guru dan alumni dari pukul 13.20 sampai dengan pukul 15.20.

Selama dua hari yaitu hari Selasa dan Kamis siswa dibawah bimbingan guru mengikuti kegiatan pengayaan pelajaran. Kegiatan pengayaan adalah kegiatan belajar mengajar yang dimaksudkan untuk perluasan dan pendalaman bahan kajian atau pelajaran bagi siswa yang telah mencapa: tingkat penguasaan minimal atau lebih awal daripada rata-rata siswa lainnya (Kurikulum Sekolah Menengah Umum, Depdikbud, 1993). Hari Rabu mereka mendapat bimbingan belajar dari alumni dan hari Senin digunakan untuk mengikuti tambahan belajar bahasa asing. Kegiatan ini wajib diikuti oleh semua siswa baik kelas satu, kelas dua, maupun kelas tiga. Siswa kelas satu dan kelas dua diwajbkan untuk mengikuti kegiatan ekstra kurikuieryang sesuai dengan minat dan bakat mereka pada hari Jum'at dan Sabtu. Ekstra kurikuler itu seperti komputer, kelompok ilmiah, olahraga, pecinta alam, kegiatan kerohanian, dan kegiatan lain yang dikelola oleh OSIS. Kegiatan ini juga diikuti setelah jam sekolah.

Suatu sekolah ungguian menurut, Elida Agoes, (Republika, 27 Agustus 1996) harus setingkat ıbih maju dalam prestasi belajar dibandingkan dengan sekolah-sekolah lain. SMU plus diproyeksikan untuk dapat dijadjkan pusat keunggulan (agent of excelience), sehingga mampu memberikan persaingan yang sehat dan motivasi bagi SMU tain di wilayahnya dalam hal prestasi sekolah. SMU plus dinyatakan berhasil apabila menunjukkan hasil kelulusannya memiliki nilai rata-rata NEM 7,00 atau lebih untuk semua jurusan (program), memiliki tingkat keberhasilan yang tinggi untuk masuk PTN ternama, memiliki kelebihan dalam pengeiolaan sekolah khususnya dalam pengembangan dan pengayaan kegatan belajar mengajar, dan pengelolaan kegiatan ekstrakurikuler yang menunjang siswa berbakat khusus (Dikdasmen, 1996).

Tidak semua siswa sekolah unggulan sanggup untuk mengikuti kebijakan sekolahnya. Pada tanggal 26 Agustus 1996, sekitar 1200 siswa Sekolah Menengah Umum Negeri 8 Bukit Duri, Jakarta Selatan, melakukan mogok belajar. Para siswa yang ditetapkan sebagai sekolah unggulan tingkat DKI Jakarta itu memprotes kebijakan kepala sekolah yang salah satunya adalah penambahan waktu belajar untuk mata pelajaran yang diebtanaskan. Aturan baru yang dikeluarkan kepala sekolah tersebut menurut para siswa benar-benar menguras otak dan tenaga siswa, sehingga waktu mereka benar-benar habis seharian di sekolah. Siswa jug a harus mengerjakan pekerjaan rumah yang selalu dibebankan oleh masing-masing guru dan biasanya juga setingkat lebih banyak dari sekolah lain (Republika, Selasa 27 Agustus 1996). Di satu sisi, kebijakan sekolah yang seperti ini sangat baik, sehingga siswa tidak menggunakan waktu luangnya untuk bermain yang tidak jelas tujuannya yang mungkin berdampak buruk bagi perkembangannya ataupun mengganggu masyarakat, misanya tawuran. Akan tetapi, siswa sekolah tersebut sesuaidengan tahap perkembangannyajuga membutuhkan waktu-waktu di uar jam belajamya untukjalan-jalan, bermain, mengikuti suatu kegiatan di luar sekolah, atau rekreasi.

Awai masuknya siswa ke SMU merupakan masa penyesuaian diri yang sangat 
berat. Menurut Thomas Holmes dan Richard Fahe (1967), awal dan akhir sekolah, masing-masing merupakan sesuatu yang terukur sebagai stres dalam kehidupan manusia (Sarafino, 1990). Dalam rangka penyesuaian diri, individu tidak lepas dari tuntutan yang berasal dari luar dirinya, yaitu lingkungan fisik maupun lingkungan sosial. Para pelajar sekolah unggulan biasanya mempunyai tanggung jawab yang lebih dari pelajar di sekolah lain karena mereka dituntut agar senantiasa menunjukkan prestasi yang optimal baik akademik maupun non akademik. Tuntutan dan harapan sekolań agar anak didiknya berprestasi lebih bak dari siswa sekolah lain bisa dipersepsi secara berbeda oleh para siswa. Tuntutan dan harapan tersebut blsa dijadikan motivator bagi sebagian siswa untuk lebih berprestasi atau malahan menjadi beban bagi siswa yang bin untuk memenuhi harapan sekolahnya.

Banyaknya harapan dan tuntutan dapat menjadi sumber stres siswa. Menurut Sumintardja (1996), individu yang dari segi kecerdasannya menunjukkan potensi yang tergolong rata-rata atau bahkan superior akan lebih mudah mengalami frustrasi, merasa tegang, atau bahkan hilang keyakinan dirinya untuk menjalani tuntutan hidup yang dihadapinya, terutama dalam hal persaingan di bidang akademik.

Lazarus dan Folkman $(1984 ; 84)$ menyatakan bahwa, situasi baru dapat menimbulkan stres hanya jka sudah ada asosiasi sebelumnya dengan kerusakan, ${ }_{\mathrm{r}}$ budaya, atau penguasaan (mastery). Para siswa, terutama siswa kelas satu, harus menyesuaikan diri dengan situasi baru di sekolahnya, dengan aturan-aturan di sekolah, dan dengan tuntutan-tuntutan sekolah yang bisa jadi sangat berbeda dengan kondisi sekolahnya yang lama. Siswa juga harus menyesuakkan diri bahwa saa ini bukanlah saltsatunya siswa dengan prestasi yang paling baik dibandingkan siswa lain seperti saat mereka duduk di sekolah menengah pertama. Di SMU N 8 Jakarta sering dijumpai ada anak kelas satu yang menangis d kelas tanpa sebab yang jelas. Mereka menangis mungkin karena nilai ujiannya jelek, merasa tertekan, atau kerena faktor lain. $\mathrm{Hal}$ ini biasanya terjadi di awal-awal masuk sekolah atau pada saat catur wulan pertama (Republika, 27 Juli 1997).

Sebagian besar siswa kelas satu me rasakan hal-hal yang berhubungan dengan pelajaran merupakan sesuatu yang meresahkan di sekolah. Misalnya, pelajaran yang sulit mereka pahami, saa ada ulangan, banyak tugas dan pekejaan rumah, dan adanya perpanjangan waktu belajar. Sebagian siswa ada juga yang menganggap faktor kelelahan di jalan dan adanya teman yang tidak sopan menjadi hal yang meresahkan mereka di sekolah.

Stres yang dialami siswa seringkali merupakan hasil persepsi yang subjektif terhadap adanya ketidaksesuaian antara tuntutan lingkungan --baik pihak sekolah dengan aturan-aturannya, numah dan anggota keluarga, serta lingkungan sosial yang laindan sumber daya aktual yang dimiliki siswa. Kondisi stres yang siswa alami sering tergantung pada hasil dari penilaian yang dibuat dalam transaksinya dengan lingkungan. Ketika siswa menilal kecocokan antara tuntutan-tuntutan dan sumber daya yang ia miliki, siswa kurang mengalami stres, tetapi ketika penilaiannya menunjukkan kesenjangan, khususnya jika siswa menilai tuntutan lebih besar daripada sumber daya yang dimiliki, dapat menimbulkan stres pada yang bersangkutan.

Penelitian ini dilakukan di SMU N 8 Jakarta dengan sampel penelitian siswasiswa kelas satu. Berdasarkan informasi yang didapat, kebijakan-kebijakan yang dibuat SMU N 8 Jakarta berbeda dengan sekolah negeri lainnya. Kebijakan itu 
misalnya, adanya pemberian tambahan pelajaran yang dikelola oleh guru dan alumni yang wajib dikuti oleh semua siswa sejak kelas satu. Hal ini membuat siswa merasa resah karena ketika sampai rumah mereka sudah kelelahan. Adanya tambahan pelajaran tersebut diduga menupakan faktor yang berkaitan dengan adanya stres siswa d sekolah dan menyebabkan terjadinya kasus mogok belajar pada siswa-siswa di SMU N 8 Jakarta.

\section{DASARTEORI}

Stres. Menurut Sarafino (1990), stres dikonseptualisaslkan ke dalam tiga cara. Pendekatan pertama menekankan pada lingkungan, stres digambarkan sebagai sebuah stimulus. Peristiwa atau keadaan yang dipersepsikan sebagai ancaman atau bahaya akan menghasilkan perasaan tegang dan hal ini disebut sebagai stressor. Termasuk ke dalam pendekatan ini adalah tekanan yang bersumber dari peristiwa bencana alam, seperti tomado dan gempa bumi; peristiwa besar dalam hidup, seperti kehilangan orang yang dicintai atau pekeriaan; dan keadaan yang lebih parah, seperti hidup dalam kepadatan atau situasi yang bising.

Pendekatan yang kedua memperlakukan stres sebagai respon, titik tekannya pada reaksi orang-orang terhadap stressor (penyebab stres). Bisa dilihat sebagai contoh pendekatan ini ketika orang-orang menggunakan kata stres untuk menunjukkan keadaan tegang mereka. Respon mempunyai dua komponen yang behubungan. Komponen psikologis yang termasuk d dalamnya tingkah laku, pola pikir, can emosi, seperti saat tegang. Komponen fisiologis mencakup gerakan tubuh yang meningkat - detak jantung, mulut terasa kering, perut terasa tegang dan berkeringat. Respon psikologis dan fisiologis seseorang terhadap stressordinamakan strain.

Pendekatan yang ketiga menggambarkan stres sebagai proses, termasuk di dalamnya stressor dan strain, ditambah dimensi yang penting yaitu hubungan antara individu dan lingkungan (Sarafino, 1990). Termasuk dakam proses ini adakh interaksi dan penyesuaian diri yang berlangsung secara kontinyu - dinamakan transaksiantara individu dan lingkungan, yang satu mempengaruhi dan dipengaruhi oleh yang lain. Terkait dengan pandangan ini, stres tidak hanya sebuah stimulus dan sebuah respon, tetapi lebih dari sebuah proses yaitu individu sebagai perantara yang aktif dapat mempengaruhi tekanan stressor melalui tingkah laku, pikiran, dan strategi emosional. Orang-orang berbeda dalam jumlah stres yang mereka alami dari stressoryang sama, sepertl misalnya terjebak kemacetan lalu lintas atau kehilangan pekerjaan. Ada orang yang terjebak lalu lintas dan akan terlambat datang pada suatu pertemuan penting selalu melihat jam tangannya, membunyikan klakson, dan menjadi marah untuk beberapa menit, tapi ada orang lain yang berada dalam situasi yang sama tetap tenang, memutar radio, dan mendengarkan musik.

Sarafino (1990) menjelaskan pengertian stres sebagai berikut:

"Stress is the condition that results when person invironment transactions lead the individual to perceive a discrepancy-whether real or not-between the demands of a situation and the re. sources of the person's biological, psychological, or social systems"

Stres menuntut faktor-faktor biopsikososial individu untuk melakukan strategi penanggulangan dengan peristiwa atau keadaan yang sulit. Faktor-faktor Ini terbatas. Contoh kondiși yang secara tiba-tiba menekan yang menegangkan faktor-faktor biopsikososial seseorang adalah menjadi 
terluka dalam suatu kecelakaan atau menjadi mual sebelum pertunjukan.

Tuntutan dari suatu situasi mengacu pada banyaknya faktor-faktor yang tampak dituntut oleh penyebab stres (stressor). Diskrepansi atau ketidaksesuaian terjadi ketika ada ketidakcocokan, atau ketidaksepadanan antara tuntutan-tuntutan situasi dan faktor-faktor individual sebagaimana dipersepsikannya. Hal penting yang tidak boleh dilupakan adalah bahwa diskrepansi itu mungkin tidak nyata dan hanya berupa kepercayaan. Misalnya, jika seseorang akan menghadapi ujian dan ingin mengerjakannya dengan baik, tetapi ia merasa sangat cemas tidak akan dapat mengerjakannya. Jika individu hanya santai saja dan tidak mempersiapkan diri untuk menghadapi tes tersebut, diskrepansi dapat dilihat antara tuntutan-tuntutan dan sumberdayanya yang mungkin nyata. Tapijika pemah mengerjakan dengan baik ujian yang sama sebelumnya, mempersiapkan dengan sungguhsungguh untuk tes yang satu ini, dan mendapat nilai bag us untuk ujian sebelumnya tetapi masih berpikir tidak dapat mengerjakan dengan bak, diskrepansi dapat dilihat tidak menunjukkan suatu keadaan yang benar. Stres yang dialami orang seringkali merupakan hasil dari persepsi yang tidak akurat dari diskrepansi antara tuntutan lingkungan dan sumber daya aktual yang dimilikinya.

Penilaian individu terhadap diskrepansi antara tuntutan dan sumber daya terjadi melalui transaksinya dengan lingkungan. Transaksi ini dipenganuhi oleh banyak faktor, termasuk di dalamnya masa lalu atau peristiwa sebelumnya dan aspek-aspek yang secara langsung mempengaruhi situasinya. Misalnya, ketika siswa mengikuti ulangan umum bersama (UUB) di sekolah saat itu. Transaksi yang berhubungan dengan UUB ini dimulai jauh sebelum UUB berlangsung. seperti ulangan-ulangan yang diikuti sebelumnya, keberhasilan dan kegagalan dalam ulangan tersebut, serta pengulangan pelajaran dan latihan soal yang dilakukan. Selama ulangan berlangsung, transaksi yang terdahulu mempunyai pengaruh pada transaksi yang sedang berlangsung di mana terjadi penilaian terhadap kemampuan pada diri siswa itu sendiri.

Definisi stres yang mengarahkan penelitian ini berdasarkan pendekatan yang ketiga yang menggambarkan stres sebagai proses di mana termasuk di dalamnya peristiwa atau keadaan yang dipersepsikan sebagai ancaman yang akan menghasilkan perasaan tegang serta respon psikologis dan fisiologis individu termasuk penyebab stres dan adanya interaksi dan penyesuaian diri yang berlangsung terus menerus antara individu dan lingkungan.

Penilaian-penilaian terhadap peristiwa yang menimbulkan stres mencakup tiga hal, yaitu:

Bahaya dan hilang (ham-loss) mengacu pada besamya kerusakan yang sudah terjadi, seperti saat seseorang menjadi tidak mampu dan terus merasakan sakit yang sangat.

- Ancaman (threat) merupakan pengharapan atas bahaya yang akan datang contohnya, siswa yang memikirkan kemungkinan gagal dalam ujian atau mendapat nilai jelek.

口 Tantangan (challenge) adalah kesempatan untuk mencapai pertumbuhan, penguasaan (mastery), atau keuntungan dengan menggunakan lebih dari faktorfaktor rutin untuk memenuhi kebutuhan. Contohnya, pemberian pekerjaan rumah atau tugas dengan tingkat yang lebih tinggi mungkin dilihat sebagal sesuatu yang dapat menimbulkan stres oleh siswa, tetapi juga dapat menjadi peluang baik untuk melatih diri agar terbiasa mengerjakan soal-soal dan menunjukkan kemampuan. 
Terkadang pengalaman stres muncut ketika stressortidak secara langsung berhubungan dengan individu. Jika seseorang melihat orang lain dalam keadaan stres, seperti menderita akibat sakit atau terancam hidupnya karena sakit, ia mungkin berempati dengan perasaannya dan merasa terluka sendiri.

Kondisi stres yang dialami sering tergantung pada hasil dari penilaian yang dibuat dalam transaksi dengan lingkungan. Ketika individu memutuskan kecocokan antara tuntutan-tuntutan dan sumber daya, ia akan mengalami sedikit atau tidak stres, tapi ketika penilaiannya menunjukkan kesenjangan, khususnya jika menilai tuntutan lebih besar daripada sumber daya akan merasa sangat stres.

Faktor yang Cenderung Mempengaruhi Penilaian Stres. Penilaian kejadian yang dapat menimbulkan stres tergantung dua jenis faktor, yaitu faktor-faktor yang berhubungan dengan individu dan yang berhubungan dengan situasi (Sarafino, 1990). Termasuk faktor individual adalah kecerdasan, motivasi, dan sifat-sifat dalam kepribadian. Misalnya, siswa dengan harga diri yang tinggi kemungkinan percaya bahwa mereka mempunyai modal untuk memenuhi tuntutan sekolah yang mementukan kekuatan yang dimilikinya. Apabila merasa suatu peristiwa dapat menimbulkan stres, mungkin individu mengartikan hal itu sebagai tantangan bukan sebagai ancaman (Cohen \& Lazanus, 1983 dan Sarafino, 1990).

Ada beberapa faktor situasi yang dapat membuat stres. Pertama, peristiwa yang dapat menimbulkan tuntutan yang sangat kuat dan mengancam cenderung dilihat sebagai sesuatu yang dapat menimbulkan stres (Sarafino, 1990). Masa transisi dalam hidup juga dapat menjadi sesuatu yang dapat menimbulkan stres (Sarafino 1990). Kehidupan punya ban yak peristiwa besar d mana tanda keberhasilannya dari satu kondisi atau fase ke yang lain dan menghasilkan perubahan yang penting serta Ituntutan baru dalam hidup. Peristiwa-peristwa yang disebut transisi, antara lain: awal perawatan atau sekolah; pindah ke daerah baru; memasuki usia pubertas, dengan diikuti perubahan biologis dan sosial; mulai kuliah, terutama jauh dari rumah; mulai bekerja; menikah; menjadi orang tua; dan pensiun dari pekerjaan.

Ambiguitas/kehilangan kejelasan suatu situasi, dapat berdampak pada penilaian stres. Dampaknya tergantung tipe ambiguitas yang muncul. Ambiguitas peran terjadi ketika informasi tentang fungsi atau tugas seseorang tidak jelas atau rancu (Sarafino, 1990). Dalam dunia kerja, misalnya, hal ini terlihat pada ketidakjelasan petunjuk, standar penampilan kerja, dan konsekuensi dari hubungan pekerjaan dan aktivitas. Ambiguitas peran sering menaikkan stres orang karena berada dalam ketidakpastian tentang tindakan dan keputusannya. Dampak pada stres berubahwah dan tergantung sekali pada kepribadian, kepercayaan, dan pengalaman umum yang dimiliki individu (Sarafino, 1990).

Satu aspek situasi yang mempengaruhi penilaian stres adalah kemampuan mengontrol, - yaitu apakah individu punya kemampuan untuk mengubah atau mengakhiri sumber stres. Orang cenderung menilai suatu peristiwa yang tidak dapat dikontrol lebih menimbulkan stres daripada peristiwa yang dapat dikontrol walaupun sebenamya tidak melakukan apa-apa untuk mempenganuhinya (Sarafino, 1990). Ada dua jenis hal yang dapat dikontrol, yaitu tingkah laku dan kognitit. Seseorang dapat melakukan kontrol tingkah laku dengan mempengaruhi akiba: dari peristiwa tersebut dengan melakukan suatu tindakan. Contohnya, apabila seseorang merasakan sakit kepala. Jika ia mampu mengurangi rasa sakit, kemungkinan akan kurang merasa 
stres akibat sakit kepala daripada tidak memiliki kemampuan tersebut. Individu dapat melakukan kontrol kognitif dengan mempengaruhi akibat dari suatu peristiwa menggunakan beberapa strategi mental, seperti mengalihkan perhatian dari sumber stres atau membangun rencana untuk menyelesaikan masalah.

Dampak Biopsikososial Stres. Stresor dapat menghasilkan tekanan pada sistem biologis, psikologis, dan sosial seseorang. Setiap orang punya pengalaman yang sangat mencemaskan dan menegangkan. Kecemasan dan ketegangan ini akan mempengaruhi terjadinya aktivitas yang berlebihan dari kerjanya organ-organ tubuh termasukk ketenjar-kelenjar hormonal sehingga menimbulkan produksi hormon-hormon. Reaksi fislologis terjadi seperti jantung berdegup dan nafas terengah-engah, otototot gemetar terutama kaki dan tangan.

Walter Cannon (1929) dalam Sarafino (1990), memberikan gambaran dasar mengenal reaksi tubuh terhadap keadaan darurat. Reaksi ini dinamakan respon fightatau -fightsebab hal iri disiapkan organisme untuk menyerang ancaman atau untuk melarikan diri. Pada respon figh-atau flight. persepsi terhadap bahaya disebabkan sistem saraf simpatik mens timulasi kelenjar adrenal pada sistem endoktrin untuk mensekresi epineprin, yang mana akan merangsang tubuh untuk bereaksi. Canon menyatakan bahwa keterbangkitan tubuh ini mempunyai dua akibat positif dan negatif. Respon figh- atau -fight adalah tingkah kku adaptasi karena menggerakkan organisme untuk berespon secara cepat terhadap bahaya, tetapi keadaan keterbangkitan yang tinggi dapat membahayakan kesehatan jika hal itu berlangsung dalam waktu lama.

Aspek biologis juga dapat menjadi sumber stres bagi seseorang. Hambatan biologis ini misalnya, tubuh yang tidak sehat, kecerdasan yang terbatas, dan kehilangan kekuatan, energi, atau keterampilan. Seorang siswa akan menjadi frustasi apabila menyadari bahwa temyata tidak memiliki kecerdasan yang dibutuhkan untuk dapat mengikuti pelajaran d sekolah unggulan.

Ada keterkaitan antara sistem biologis, psikologis, dan sosial seseorang ketika mengalami stres. Stres menghasilkan perubahanperubahan fisiologis, tetapi faktor psikososial juga mempunyai peranan. Stres juga berakibat pada kognisi, emosi dan sistem sosial seseorang. Reaksi-reaksi fisiologis dan organis akan berdampak pada individu, misainya menjadi lesu, tidak bergairah, atau sedih berkepanjangan. Hal ini akan berdampak ke dalam kehidupan sosial seseorang.

Aspek psikologis dan sosial juga dapat menjadi sumber stres bagi seseorang. Misalnya, seorang pelajar menjadi frustrasi karena ternyata ia tidak tertarik dengan sekolah yang telah dipilihnya. Lingkungan atau keluarga di mana ia tinggal tidak akan menyetujui apabila a memutuskan untuk keluar saja dari sekolah hanya karena alasan tidak tertarik dengan sekolah terse but, apalagi jika ia bersekolah di sekolah unggulan.

Aktivitas Kognitif dan Stros. Banyak siswa yang telah mengalami pengalaman sebagai berikut: saat melakukan ujaan yang menimbulkan stres of sekolah, mungkin salah menafsirkan informasi penting yang ada dalam pertanyaan atau mendapat kesulitan untuk mengingat jawaban yang telah mereka pelajari dengan baik sebelumnya. Akan sangat mengesalkan apabila mengetahui jawabannya tapi susah untuk mengingatnya kembali saat hendak menjawab soal, apalagi jika mungkin teringat kembali setelelah ujian itu selesai. Tingkat stres yang tinggi dapat mengganggu ingatan dan perhatian seseorang selama melakukan aktivitas kognitif (Sarafino, 1990).

Emosi dan Stres. Emosi cenderung menyertai stres dan orang sering menggunakan 
keadaan emosi mereka untuk mengevaluasi stres. Proses penilaian individu terhadap stimuli yang diamati dapat mempengaruhi pengalaman stres dan emosinya (Sarafino, 1990).

Hal-hai khusus yang orang takutkan berhubungan dengan usia (Sarafino, 1990). Selama masa kanak-kanak hal-hal yang ditakuti sifatnya kurang kongkrit atau nyata serta menjadi lebih abstrak dan lebih sosial saat mereka semakin besar. Pada akhir masa kanak-kanak, kecemasan yang berhubungan dengan sekolah, kemampuan individu dan hubungan sosial menjadi semakin jelas. Anak-anak semakin menyadari perbedaan satu sama lain dan mereka membandingkan dengan temannya kemampuan akademis, perilaku, bakat, keindahan fisik, dan popularitas. Anak-anak yang melihat diri mereka kurang mampu dibandingkan teman sebayanya kemungkinan menilai sumber daya mereka tidak cukup untuk memenuhi tuntutantuntutan penyebab stres.

Akibat stres itu luas yang melibatkan peranan antara sistem biologis, psikologis, dan sosial bahkan pada saat penyebab stres itu sendiri sudah tidak ada. Dampak pengalaman stres dapat bertarijut. Beberapa orang mengalami stres yang leblh daripada orang lain. Stes muncul dari berbagai sumber yang tidak terhitung dan di setiap saat dalam kehidupan manusia.

Tidak semua stres bersifat negatif atau tidak sehat. Ada juga stres yang sifatnya netral dan mungkin bagus buat seseorang. Menurut Selye $(1974,1985)$ dalam Sarafino (1990), jenis stres yang pertama adalah merugikan dan merusak, dinamakan distress, jenis yang bermanfaat dan membangun, dinamakan eustress. Lazarus juga menggambarkan tiga tipe penllaian stres, yaitu ham-loss, threat, dan challsnge. Orang yang tertantang lebih memiliki semangat yang lebih balk, karena menjadi tertantang berarti merasa positif akan tuntutan yang akan dihadapinya, dan hal ini terpancar dari emosl yang menyenangkan yang menyertai tantangan. Respon fisiologis stres terhadap tantangan berbeda dari yang dilihat sebagai ancaman, sehingga gangguan dalam adaptasinya sangat sedikit terjadi (Lazarus \& Folkman, 1984, 34).

Persepsi. Individu hidup dalam dunla benda dan manusia, suatu dunia yang membanjiri indera dengan berbagai stimulus. Segala informasi tentang dunia ini sampai melalui indera. Indera ini dapat mengingatkan individu akan bahaya dan memberlkan informasi yang ia butuhkan untuk menafsirkan berbagai perlstiwa dan mengantlsipasi masa depan. Persepsi diketahui dari cara kerja mekanisme indera, bagaimana indera tersebut menerima sensasi cahaya sumber sentuhan, dan rasa Persepsi tidak hanya meliputi pembedaan stimulus (ransangan) sederhana karena organisme tubuh mengartikan dan memberikan reaksi pada pola-pola stimulus. Persepsi dapat menyerap informasi dari susunan stimulasi yang ada di sekitamya.

Pengalaman inderawi akan terjadl sesudah adanya ransangan minimum dari salah satu indera. Daya atau kekuatan fisik minimum yang dibutuhkan untuk menggerakkan sistem saraf tertentu disebut ambang mutlak (absotut threshold). Anbang mutlak ini akan berbeda dari satu individu ke individu yang lain. Ambang untuk individu tertentu akan berbeda pula dari waktu ke waktu tergantung pada kondisi fisik orang tersebut dan motivasinya.

Menurut Hilgard dan Atkinson (1991), persepsi diartkan sebagal proses mengorganisaslkan dan menafsirkan pola stimulus hi dakam lingkungan. Individu bukanlah penerima rangsangan pasif. Otak secara aktif mengolah Informasi yang diterima dan mengubahnya dalam bentuk dan kategori baru. 
Persepsi mengacu pada cara bagaimana seseorang menginterpretasikan stimulus yang ada di lingkungan. Stimulus mungkin sangat lemah sehingga individu tidak menyadari keberadaannya. Persepsi terhadap stimulus tersebut akan mempengaruhi pikiran individu. Setiap individu mempunyai persepsi yang berbeda walaupun terhadap obyek yang sama. Hal ini terutarna dipengaruhi oleh stimulus ku sendiri dan keadaan individu, seperti pengalaman masa lalu, suasana hati, dan kebutuhan individu yang bersangkutan. Stimulus yang disadari secara pasti keberadaannya dan bermakna buat seseorang akan lebih efektif mempengaruhi tingkah laku daripada stimulus yang kurang berarti bagi seseorang.

Menurut Forgus (1966), persepsi merupakan istilah umum untuk menggambarkan proses menyeluruh dari bagaimana seseorang menjadi tahu apa yang terjadi di sekelilingnya. Cara individu memperoleh pengetahuan tentang lingkungannya ini merupakan hal yang sangat penting dalam hubungannya dengan tingkah laku penyesuaian diri individu. Hanya stimulusstimulus yang mempunyai makna saja yang akan menghasikan reaksi atau tingkah laku penyesualan diri individu.

Tuntutan dan Harapan of Sekolah Plus. Ilmu psikologi membahas penyesuaian diri individu dalam lingkungannya. Titik tekan penyesuaian dirl adalah pada dua jenis tuntutan. Pertama adalah tuntutan daridalam, yang muncul dari sifat tubuh seseorang. Misalnya, kekurangan makan dan air, rasa sakit, atau tubuh membutuhkan rasa hangat karena kedinginan. Jenis lain dari tuntutan dasar adalah tuntutan eksternal, di mana tuntutan tersebut muncul dari lingkungan fisik luar dan lingkungan sosial individu. Tuntutan sosial umurnnya dianggap oleh para psikolog merupakan hal yang paling penting untuk menjelaskan kehidupan emosi manusia, baik emosi yang sifatnya positif maupun emosi yang dianggap negatif sifatnya. Hal ini karena tiap individu hidup saling tergantung dengan individu lain. Tuntutan sosial yang dimulai dari luar, yaitu tekanan yang nyata atau yang dibayangkan dari orang lain seperti bertindak dengan cara tertentu, pengharapan akan bagaimana seharusnya individu berfikir dan merasakan nantinya menjadi bagian dari dalam diri individu pada saat individu mulai menganggap tekanan-tekanan ini sebagai bagian dari dirinya sendiri. Contohnya, keinginan untuk mendapatkan penghargaan dari masyarakat yang tinggi mungkin sudah dimulai sebagai nilai-nilai dari orang tua atau masyarakat. Nilai-nilai seperti itu dikemudian hari bisa menjadi tuntutan internal dalam kepribadian individu.

Tuntutan diartikan sebagal aspek apapun dari lingkungan yang bisa memunculkan dorongan-dorongan di dalam organisme. Sedangkan harapan adalah satu sikap yang dicirikan dengan satu pengharapan akan hasil atau peristiwa yang baik dan menyenangkan. Pada penelitian ini, tuntutan dan harapan sekolah diartikan sebagai segala sesuatu yang berasal dari sekolah yang mengharuskan siswa untuk bertingkah laku sesuai dengan sikap sekolah agar mereka dapat mencapai hasil yang baik dan menyenangkan pihak sekolah dalarn hal ini sebagai siswa sekolah unggulan atau sekolah plus.

SMU plus merupakan sekolah yang dipersiapkan oleh Kanwil Depdiknas untuk dapat dikembangkan menjadi SMU yang memiliki ciri plus, yaitu antara lain memiliki sejumlah siswa dengan bakat-bakat khusus dengan kemampuan dan kecerdasan yang tinggi; memiliki tenaga guru profesional yang handal; melaksanakan kurikulum yang diperkaya; dan memiliki sarana dan prasarana yang rnemadai.

Siswa sekolah plus merupakan objek evaluasi keberhasilan sekolah. Evaluasi 
hasil belajar siswa berupa pengetahuan keterampilan akademik, sosial, motorik, skap siswa; kepribadian, termasuk di dalamnya adalah disiplin (waktu dan aturan), toleransi, sopan santun, kerjasama, kreativitas, konsep diri, kepemimpinan, tanggungjawab; serta keimanan dan ketakwaan.

Menurut Kanwil Depdiknas, penetapan SMU negeri sebagai SMU plus didasarkan atas prestasi yang diperoleh atau memiliki sarana dan prasarana yang memungkinkan untuk dapat dikembangkan sebagai SMU plus. Sementara pengertian plus belum berarti memiliki kelebihan, melainkan merupakan beban dan tanggungjawab untuk memperoleh kelebihan.

Program kerja jangka pendek yang harus dilaksanakan SMU plus adalah pemantapan kegiatan sekolah dalam rentang waktu yang lebih lama (pukul 07.00 s.d. 15.30) dan mengadakan program pengayaan. Jika d SMU lain yang bukan plus, program pengayaan ditujukan bagi siswa yang telah mencapai tingkat penguasaan minimal lebih awal daripada rata-rata siswa lainnya, maka di SMU plus kegiatan ini wajib dikuti oleh semua siswa.

Program kerjajangka panjang SMU plus salah satunya adalah menjadi pusat keunggulan (agent of excellence) bagi sekolah di sekitarnya, sehingga dapat memberikan persaingan yang sehat dan motivasi bagi SMU lain d wilayahnya. Dengan demikian, siswa-siswa SMU plus harus bisa menjadikan dirinya contoh agar bisa ditiru oleh siswa-siswa sekolah lain dalam semua aspek yang menjadi keunggulan sekolahnya. Misalnya, berhasil dalam setiap lomba tingkat regional, nasional, maupun intemasional.

Siswa SMU plus juga harus memiliki keterampilan berbahasa Inggris karena kemampuan berbahasa inggris sangat diperlukan dalam era globalisasi. Penguasaan keterampilan betbahasa Inggris bagi siswa tidaklah mudah mengingat alokasi waktu pelajaran bahasa Inggris di sekolah kurang banyak atau cukup. Oleh sebab itu, diusahakan membuat kelompokkelompok siswa yang setiap hari berbahasa Inggris khususnya dalam kegiatan ekstrakurikuler. Di SMU N 8 Jakarta, kelompok bahasa tidak hanya ditujukan bagi siswa program bahasa yang duduk di kelas tiga saja tetapi juga diwajibkan bagi siswa kelas satu dan pillhan bahasanya juga bernacammacam, seperti bahasa Arab, bahasa Jepang, bahasa Jerman, dan bahasa Prancis.

SMU plus dinyatakan berhasil, apabila menunjukkan hasil kelulusannya memiliki rata-rata NEM 7,00 atau lebih untuk setiap jurusan (program) dan memiliki tingkat keberhasilan yang tinggi untuk masuk ke perguruan tinggi negeri ternama. Oleh karena itu, siswa SMU N 8 Jakarta harus dapat memiliki rata-rata NEM 7,00 atau lebih dan dapat masuk ke perguruan tinggl ternama agar sekolahnya dapat dinyatakan berhasil sebagai SMU plus.

Sekolah Plus. Latar belakang diadakannya sekolah plus oleh Departemen Pendidikan Nasional adalah perlunya perhatian khusus kepada peserta didik yang memiliki kemampuan dan kecerdasan yang unggul melalui sekolah-sekolah yang mengutamakan keunggulan. Hal ini selaras dengan fungsi utama pendidikan yaitu mengembangkan potensi peserta didik secara utuh dan optimal. Sejauh ini pendidikan yang memberikan perlakuan rata-rata, kurang memberikan tantangan kepada peserta didik yang memilikl kemampuan dan prestas| yang unggul untuk mewujudkan kernampuannya secara optimal. Adanya kebutuhan akan sumber daya manusia yang berkualitas tinggi yang memiliki keunggulan dalam ketahanan fisik dan mental, penguasaan ilmu pengetahuan dan teknologi, disiplin dan bertanggungjawab, memiliki 
keahlian tertentu, serta berorientasi masa depan juga melatarbelakangi pendirian sekolah unggulan (Depdiknas, Dikdasmen, 1996). Beberapa sekolah yang tidak menamakan dirinya sekolah unggulan atau plus, memberikan perlakuan yang bebeda jug a kepada siswanya yang dirasakan mempunyai kemampuan lebih dari siswa-siswa yang lain. Biasanya mereka dikumpulkan hanya dalam satu kelas unggulan saja.

Sekolah Menengah Umum (SMU) plus adalah SMU Negeri yang dipersiapkan oleh Kanwil Depdikbud untuk dapat dikembangkan menjadi SMU yang memiliki ciri plus, yaitu:

1. Memiliki sejumlah siswa berbaka! khusus dengan kemampuan dan kecerdasan yang tinggi;

2. Memiliki tenaga guru profesional yang handal;

3. Melaksanakan kurikulum yang diperkaya;

4. Memiliki sarana dan prasarana yang memadai;

Saran a dan prasarana yang dibutuhkan SMU pilus, antara lain: ruang belajar yang cukup memadal; laboratorium fisika, laboratorium kimia, laboratorium biologi dan laboratorium bahasa, serta ruang komputer yang lengkap dengan seluruh peralatannya, perpustakaan yang memiliki minimal 5000 judul dengan ruang yang cukup memadai untuk belajar sendiri; ruang atau lapangan dah raga yang dapat meningkatkan kebugaran jasmani dan prestasi; media belajar yang cukup lengkap; nang kesenian dan seperangkat alat kesenian; asrama siswa dan perumahan guru/pegawal; sarana belajar dan lingkungan memadai; buku pelajaran (paket): 1 siswa 1 buku; waktu belajar hanya satu shift; satu kelas tidak lebih dari 41 siswa; setlap kelas dilengkapi dengan OHP yang harus digunakan dalam setiap kegiatan belajar mengajar.

5. Memiliki sumberdana mandiri yang jelas dan pasti. Dengan memperhatikan kebutuhan dan kegiatan di SMU plus, akan dibutuhkan unit cost yang tinggi.

6. Dalam susunan pembina ada unsur Pemda dan bantuan dari APBD.

(Depdiknas, Dikdasmen, 1996)

Tujuan dari diselenggarakannya sekolah plus adalah:

口 Menghimpun peserta didik yang memiliki bakat khusus, kemampuan dan kecerdasan tinggi di seluruh wilayah untuk dapat dikembangkan secara optimal. Setiap wilayah djharapkan memilikl warga yang memiliki kecerdasan dan kemampuan yang luar biasa, yang dapat membangun daerah pada ke-21 ini.

$\checkmark \quad S M U$ plus diproyeksikan untuk dapat dijadikan pusat keunggulan (agent of excellence), sehingga dapat memberikan persaingan yang sehat dan motivasi bagi SMU lain di wlayahnya.

ㅁ Keberhasilan dalam setiap lomba tingkat regional, nasional, dan internasional. Setiap SMU plus diharapkan ikut serta dalam setiap pertandingan atau perlombaan karena terhimpunnya siswa berbakat khusus d sekolah ini. Kegiatan karya ilmiah remaja ditumbuhkembangkan sehingga siswa terblasa dan terlatih dalam penelitian.

๑ Memiliki keterampilan berbahasa inggris.

- Sekolah mampu menciptakan $6 \mathrm{~K}$ (ketertiban, keamanan, kebersihan, keindahan, kekeluargaan, dan kerindangan). Untuk mencapai $6 \mathrm{~K}$, RAPBS harus dapat mendukung, serta melibatkan siswa yang disertal program keria. 
SMU plus dinyatakan berhasil, apabila menunjukkan hasil sebagai berikut:

1. Kelulusan SMU plus memiliki rata-rata NEM $7, \infty$ alau lebh untuk setiap jurusan (program).

2. Memilikitingkat keberhasilan yang tinggi untuk masuk ke pergunuan tinggi negeri ternama. SMU plus harus memiliki kelebihan dalam pengelolaan sekolah khususnya dalam pengembangan dan pengayaan kegiatan belajar-mengajar. Oleh karena itu, diperlukan organisasi pengelolaan yang dapat mendukung dan melaksanakan kegiatan belajarmengajar dengan program pengayaan.

Pengelolaan kegiatan ekstrakurikuler yang menunjang siswa berbakat khusus (seni, bahasa, olahraga, itmu pengetahuan dan teknologi) harus dapat dikembangkan dengan baik.

SMU plus diharapkan mampu menghasilkan siswa yang memiliki: keimanan dan ketakwaan kepada Tuhan Yang Maha Esa, nasionalisme dan patriotisme yang tinggi dengan kepribadian pancasila, wawasan iptek yang mendalam dan luas, motivasi dan komitmen yang tinggi untuk mencapai prestasi dan keunggulan, kepekaan sosial dan kepemimpinan, disiplin yang tinggi, kondisi fisik yang prima, kegemaran membaca dan meneliti, kemampuan berbahasa yang baik dan benar, serta kemampuan berbahasa Inggris yang baik dan lancar (Depdiknas, Dikdasmen, 1996).

Sekolah unggul mempunyai banyak alternatif model penyelenggaraan: sekolah swasta dan asrama dikelola oleh yayasan; sekolah negeri dan asrama oleh yayasan; sekolah negeri dan asrama oleh pemenintah; sekolah swasta tanpa asrama; sekolah negeri tanpa asrama dibantu oleh BP3 (Depdiknas, Dikdasmen, 1996).

\section{HPOTES IS}

Ada hubungan antara persepsi siswa terhadap tuntutan dan harapan sekolah dengan derajat stres siswa di Sekolah Menengah Umum-plus.

\section{METODE}

Penelitian ini menggunakan variabel tergantung derajat stres siswa dan variabel bebas persepsi siswa terhadap tuntutan dan harapan sekolah.

Data diperoleh dengan menggunakan alat ukur persepsi siswa terhadap tuntutan dan harapan sekolah serta alat ukur derajat stres siswa.

Pada alat ukur yang pertama, siswa diminta untuk menjawab butir-buti pernyataan yang sesuai dengan yang dilihat dan dirasakan sebagai tuntutan dan harapan yang disampaikan sekolah terhadap mereka. Indikator-indikator tuntutan dan harapan sekolah diperoleh dari pihak sekolah dengan mengacu pada Kurikulum Sekolah Menengah Umum, Petunjuk Teknis Pengelolaan SMU plus, yang diterbitkan oleh Depdiknas, Dirjendikdasmen, Dirdikmenum, Jakarta, 1996. Kemudian dari indikator tersebut disusun sejumlah butir pemyataan.

Nilai yang diperoieh pada setiap pernyataan dijumlahkan sehingga memperoleh total nilai persepsi. Skor ini akan menggambarkan siswa terhadap persepsi tuntutan dan harapan sekolahnya. Semakin tinggi skor yang diperoleh, semakin menunjukkan pengetahuan siswa akan tuntutan dan harapan sekolah terhadap dirinya; sedangkan semakin rendah skor yang diperoleh, berarti slswa tidak mengetahul adanya tuntutan dan harapan sekolah terhadap dirinya.

Uji coba alat ukur dilakukan terhadap 20 orang siswa yang mempunyai karakteristik sama dengan sampel. Hasil uji coba alat ukur dengan de rajat kepercayaan $95 \%$ 
di dapat 21 item dari 27 item yang dibuat pada uji coba yang kedua, yang dapat digunakan untuk menjaring data persepsi siswa dengan nilai korelasi antara 0,3861 sampai dengan 0,7505 . Reliabilitas alat ukur ini sebesar 0,8149 .

Stres siswa diukur dengan skala yang menggunakan metode rating scale. Sebelum menyusun alat ukur, terlebih dahulu dilakukan wawancara terhadap beberapa orang siswa SMU N 8 Jakarta tentang kondisi sekolahnya dan dirinya sebagai siswa sekolah unggulan. Data tambahan diambil dari BP SMU N 8 Jakarta yaitu berupa halhal yang meresahkan siswa kelas satu ketika berada di sekolah. Kemudian dibuat indikator-indikator untuk mengukur stres yang dirasakan oleh siswa.

Dengan derajat kepercayaan $95 \%$, didapat 36 item dari 48 itern yang dibuat saat uji coba kedua, yang dapat digunakan untuk menjaring data tentang stres siswa dengan korelasi antara 0,3910 sampai dengan 0,8205 . Reliabilitas alat ukur ini sebesar0,8513.

Populasi penelitian ini adalah para siswa SMU N 8 Jakarta kelas satu. Dengan samanya kelas, diharapkan pengalaman yang diperoleh d sekolah relatif sama untuk setiap anak. Awal kelas satu dapat dikatakan sebagai salah sabu masa transisi yang dapat menimbulkan stres pada siswa. Usia mereka berkisar antara 14- 17 tahun.

Pengambilan sampel dalam penelitian ini dilakukan dengan menggunakan metode sampling acak sederhana (simple random sampling), di mana sampel diambil sedemikian rupa sehingga setiap unit penelitian atau satuan elemen dari populasi mempunyai kesempatan yang sama untuk dipilih menjadi sampel penelitian. Jumlah seluruh populasi dari siswa kelas satu Sekolah Menengah Umum Negeri 8 Jakarta berjumlah 326. Sampel yang digunakan adalah sebanyak 81 orang siswa.

\section{HASIL PENELITIAN}

Analisa statistik digunakan untuk melihat korelasi antara persepsi siswa terhadap tuntutan dan harapan sekolah dengan derajat stes siswa. Karena data dari kedua variabel ini berskala ordinal maka analisis yang digunakan adalał uj statistik Hank Speaman. Kemudian menghitung signifikansi dengan menggunakan t-test, untuk menguji apakah hipotesa ditolak atau diterima.

Data yang diperoleh adalah berupa skor persepsi siswa terhadap tuntutan dan harapan sekolah dan skor stres siswa yang menjadi sampel penelitian. Dari hasil perhitungan didapat: is $=0,4774$, thitung $=4,8291$, dengan taraf kepercayaan $95 \%$, ttabel $=1,989$. thitung $>$ ttabel sehingga tolak Ho dan terima $\mathrm{H} 1$. Hasil ini menunjukkan bahwa terdapat hubungan antara persepsi siswa terhadap tuntutan dan harapan sekolah dengan derajat stres siswa.

Dalam penelitian ini juga dihitung nilai korelasi antaraspek dari kedua variabel penelitian. Dari hasil perhitungan, didapat:

1) Aspek mencapai prestasi dan keunggulan. $r s=0,4499$, nilai thitung $=4,4775$ Jad signifikan dengan taraf kepercayaan $95 \%$.

2) Aspek pengayaan kegiatan belajar mengajar. is $=0,2266$, nilail thitung $=$ 2,0679. Jadi signifikan dengan taraf kepercayaan $95 \%$.

3) Aspek disiplin. $r s=0,1153$, nilai thitung $=1,0317$. Jadi tidak signifikan dengan taraf kepercayaan $95 \%$.

\section{PEMBAHASAN}

Dari penelitian yang dilakukan, diperoleh hasil bahwa terdapat hubungan yang positif antara persepsi siswa terhadap tuntutan dan harapan sekolah dengan derajat stres siswa. Artinya semakin siswa mempersepsikan tuntutan dan harapan sekolahnya sebagai 
ancaman dan beban, semakin tinggi stres yang cenderung dirasakan oleh siswa kelas satu di sekolah unggulan.

Stres yang dialami siswa merupakan hasil persepsi yang subjektif dari ketidaksesuaian antara tuntutan dan harapan sekolah dengan kemampuan yang dimiliki siswa. Misalnya, para guru menganggap bahwa siswa yang dapat masuk ke SMU N 8 Jakarta adalah siswa-siswa lulusan terbaik dari SMPnya masing-masing. Sehingga para guru beranggapan bahwa siswa dapat menerima materi pelajaran yang diberikannya dengan cepat. Akan tetapi, temyata ada $85,19 \%$ siswa merasa mengalami kesulitan saat guru mengajar dengan terlalu cepat. Hal ini menyebabkan $38,27 \%$ slswa menjadi frustasi karena kesulitan untuk mengikuti materi yang disampaikan dengan terlalu cepat oleh guru.

\section{ASPEK MENCAPAI PRESTAS! DAN KEUNGGULAN}

Jika dilihat hubungan antara masingmasing aspek, yang paling kuat hubungannya adalah aspek pertama, yaitu tuntutan dan harapan sekolah terhadap siswa agar mencapal prestasi dan keunggulan. Hal ini berarti bahwa tuntutan dan harapan sekolah yang dipersepsikan sebagai ancaman dan beban menjadikan siswa stres adalah tuntutan sekolah agar slswa mencapai prestasi dan keunggulan.

Salah satu indikator keberhasilan suatu sekolah pius adalah menduduki peringkat pertama rata-rata nilai ujian siswa saat UUB di wilayahnya. Untuk sekolah menengah umum negerl \& Jakarta, SMU N 8 Jakarta selalu menduduki peringkat pertama dalam nilai ujlan dibandingkan sekolah negeri lainnya. Akan tetapi, ada 40,74\% siswa yang merasa terbebani dengan keharusan mempertahankan peringkat sekolah ini.
Sebanyak $33,33 \%$ siswa merasa tegang karena guru senantiasa mengingatkan agar nilai ujlannya harus di atas rata-rata sekolah lain. Ada $62,96 \%$ siswa merasa cemas menghadapi ujlan catur wulan dan 43,21\% siswa merasa tegang saat memikirkannya. sebanyak $64,2 \%$ siswa merasa khawatir mengalami nasib bunk saat UUB dan hanya $34,57 \%$ siswa yang merasa yakin dapat mengerjakan ulangan dengan baik.

Siswa tahu bahwa sekolah menuntut dan mengharapkan mereka ikut serta dalam tumamen baik di tingkat regional, nasional, maupun intemasional, serta mengharapkannya dapat menang atas nama sekolah. Tetapl sIswa tidak begitu merasakan tuntutan dan harapan sekolah kepada siswa agar menang jika bertanding di tingkat regional/daerah, Hal ini terjadi mungkin karena siswa adalah siswa sekolah unggulan tingkat propinsi sehingga merasa sudah sewajamya kalau menang dalam tumamen yang dijkuti di tingkat daerah. Ada sejumlah $38,27 \%$ siswa merasa stres karena harus menjaga nama baik sekolah. Sebanyak $29,63 \%$ siswa merasa terbebani dengan tuntutan sekolah yang berlebihan terhadap mereka.

SMU plus harus memiliki tingkat keberhasilan yang tinggi dalam memasukkan siswanya ke perguruan tinggi negeri temama. Tuntutan dan harapan sekolah ini biasanya lebih ditujukan buat siswa kelas tiga yang sebentar lagi akan lulus dan diharapkan dapat melanjutkan pendidikannya ke jenjang yang lebh tinggi lagi. Tuntutan dan harapan ini tidak begitu ditekankan oleh pihak sekolah kepada siswa kelas satu. Akan tetapl, sekitar $59,26 \%$ s|swa kelas satu yang dijadikan sampel penelitian merasa khawatir tldak dapat diterima di perguruan tinggi negeri ternama setelah lulus nanti.

Walaupun siswa yang diterima di SMU N 8 Jakarta ini adalah Iulusan terbaik di SMPnya masing-masing (dilihat dari Nllai 
Ebtanas Mumi SMP), ada sebanyak 48, 15\% siswa merasa risau karena teman sekelas pintar semua dan $64,2 \%$ siswa merasa khawatir tidak dapat menyamai prestasi siswa lain di sekolah.

Menurut guru-guru di SMU ini, pernberian ulangan sebagai evaluasi sampai sejauh mana siswa memahami bahan pelajaran yang telah diberikan oleh guru, tidak dilakukan setiap hari, tergantung program. Walaupun demikjan, ulangan atau ujan merupakan salah satu yang menyebabkan stres bagi siswa sekolah ini. Ada 62,96\% slswa merasa gelisah saat ada ulangan mendadak dan $60,49 \%$ siswa merasa gugup saat tiba-tiba guru mengadakan ulangan. Slswa juga merasa cemas jika tiap pekan banyakdiadakan ulangan $(60,49 \%)$. Sebanyak $56,79 \%$ slswa merasa sedih karena sangat sulit memperoleh nilai bagus di ulangan.

Pada saat penelitian ini dilakukan, sampel baru menjalani tiga bulan pertama masa sekolahnya di SMU Plus. Mereka merasa belum puas dengan hasi belajamya selama ini $(85,19 \%)$. Hal ini mungkin bisa dilihat dari nilai ulangan mereka karena sebanyak $82,72 \%$ siswa merasa takut dapat nilal jelek di ulangan. Sebagai sekolah unggulan, SMU N \& Jakarta ini memang memberikan latihan soal yang tingkat kesulitannya lebih tinggi dibandingkan sekolah lain. Hal ini membuat $69,14 \%$ siswa merasa resah dengan soal ulangan akhir yang sulit.

\section{ASPEK PENGAYAAN KEGIATAN BELAJAR MENGAJAR}

Tuntutan dan harapan sekolah yang berhubungan dengan pengayaan kegiatan belajar mengajar juga siswa persepsikan sebagai ancaman dan beban sehingga membuat siswa merasa stres. Dalam rangka pengayaan materi pelajaran, selain mengadakan perpanjangan waktu belajar seusai sekolah, sekolah ini juga masih memberikan pekerjaan rumah dan tugas yang harus siswa kerjakan di rumah. Sebanyak $60,25 \%$ sampel penelitian menyatakan merasa bingung untuk menyelesaikan pekerjaan rumah yang menurut mereka terlalu banyak dan membuat $61,73 \%$ siswa merasa lesu ketika ada banyak pekerjaan rumah. Sejumlah $76,54 \%$ siswa mengalami kesulitan jika ada banyak tugas dari guru.

Sedangkan perpanjangan waktu belajar sesuai sekolah menjadikan $50,62 \%$ siswa merasa letih saat mengikutinya dan $4,94 \%$ ' siswa merasa gelisah saat mengikuti tambahan pelajaran ini.

\section{ASPEK DISIPLIN}

Tuntutan dan harapan sekolah terhadap siswa yang berupa kedlsiplinan tidak membuat siswa merasa terancam dan terbebani. Persepsi siswa terhadap disiplin yang diberlakukan pihak sekolah tidak menunjukkan hubungan yang berarti dengan stres siswa. Hal ini tejadi karena siswa yang dijadikan sampel penelitian dapat mengikuti aturan-aturan yang dibertakukan sekolah terhadapnya. Dalam penelitian ini aspek kedisiplinan kurang tergali secara mendalam dibandingkan dua aspek yang lain, sehingga antara persepsi siswa terhadap tuntutan dan harapan sekolah agar disiplin tidak mempunyai hubungan yang berarti dengan stres siswa.

Salah satu hal yang diharapkan oleh SMU plus adalah dapat menghasilkan siswa dengan disiplln yang tinggl. Untuk menjunjung hal ini, diperlukan kerjasama yang baik darl semua pihak o sekolah. Suasana yang penuh kedislplinan sangat terasa di SMU N8 Jakarta. Saat bel masuk berbunyi pukul 06.45, petugas satpam sudah harus menutup gerbang sekolah. Lingkungan sekolah ini sangat tertutup dan selalu dijaga 
oleh petugas keamanan. Dari penelitian didapat data bahwa ada $44,44 \%$ siswa merasa tegang ketika ada guru yang marah atas ketidakdisiplinan mereka. ada enam orang atau $7,41 \%$ siswa merasakan kedisiplinan yang diterapkan di sekolah berat buat mereka. Sebanyak $22,22 \%$ siswa merasa terbebani dengan peraturan sekolah dan $14,82 \%$ siswa merasa terbebani dengan menjadi siswa sekolah unggulan. a

\section{DAFTAR PUSTAKA}

Ahrnady, Z.A. 1995. Dirjen Dikdasmen Depdikbud Jakarta. Sekolah Unggulan dalam Kerangka Kebijaksanaan Pengembangan Pendidikan Nasional. Seminar Pendidikan "Sekolah Unggulan dalam Konteks Pendidikan untuk Semua". SMAUII. Yogyakarta.

Atkinson, R. L., Atkinson, Richard C., \& Hilgard, Ernest R. 1991. Pengantar Psikologi. Edisi kedelapan - jilid satu. Penerbit Erlangga. Jakarta.

Cohen, R. J. 1988. Psychological Testing. Maylield Publishing. Company. Califomia.

Depdikbud. Dirjendikdasmen, 1996. Sekolah Menengah Umum Plus. Halaman 1-7. JRR, Jumal Rehabilitasidan Remediasi. No. 14 Th V 1996. diterbitkan oleh Pusat Penelltian Rehabilitasi dan Remediasi (PPRR) Lembaga Penelitian UNS. Surakarta.

Departemen Pendidikan dan Kebudayaan, Direktorat Jenderał Pendidikan Dasar dan Menengah, Direktorat Pendidikan Menengah Umum. 1996. Kurikulum Sekolah Menengah Umum (SMU), PetunjukTeknis Pengelolaan SMU Plus. Jakarta.
Engle, T.L. \& Snellgrove, L. 1989. Psychology its Principles and Applicationas. Ninth Edition. Harcourt Brace Jovanovich Publishers. Orlando.

Forgus, R.H. 1966. Perception The Basic Progress in Cognitive Development. McGraw Hill Book Company. New York.

Gage, N.L. \& Berliner, D. C. 1979. Educa tional Psychology. Second Edition. Rand College Publishing Company. USA.

Hasnida. 1995. Derajat Stres, Tingkat Kecemasan, dan Strategi Penanggulangan pada Mahasiswa Tingkat Akhir. Skrips| Fakultas Psikologi Universitas Padjadjaran. Bandung.

Lazarus, Richard S. 1976. Patterns of Adjustment. Third Edition. McGraw-Hill. Kogakusha, Ltd. Tokyo.

\& Folkman, Susan. 1984. Stress, Appraisal, and Coping. Springer Publishing Company. New York.

Lewin, M. 1979. UnderstandingPsychological Research. The Student Researcher's Handbook. John Willey \& Sons. New York.

Nazir, M. 1983. Metode Penelitian. Ghalia Indonesia. Jakarta.

Sarafino, E. P. 1990. Health Psychology Biopsychosocial interaction. Trenton State College. John Willey \& Sons. New York.

Sumintardja, E. 1996. Insan Berkualitas Dengan Ciri Pola Penanggulangan Yang Proaktif Serta Kreatif Terhadap Stres. Oras IImiah Lustrum VII Fakutas Psikologl Unpad. Bandung. 